\title{
Kesetaraan Gender dalam Sastra Pesantren (Kajian terhadap Kitab Syi'ir Laki Rabi)
}

\author{
Moh. Muzakka Mussaif \\ Fakultas Ilmu Budaya Universitas Diponegoro \\ Email: muzakkamoh@yahoo.co.id
}

\begin{abstract}
Gender issues are discussed in many literary works, whether they are foreign literature, Indonesian literature, or regional literature. Gender issues also appear in religious literature and or pesantren literature. Most of the gender issues that arise in religious literature and or pesantren are issues of gender bias or gender imbalances that are confirmed by the arguments of the Qur'an and the hadith of the Prophet. However, in the literature study of pesantren with the approach of feminist literary criticism of the Sy'ir Laki Rabi by Haji Zakaria did not show any gender bias. The results show that the gender issues raised in this poem are not loaded with gender bias. This work, though, speaks of domestic life, but it emphasizes the duties, duties, and rights of husband and wife.
\end{abstract}

Keywords: syi'ir, literature, pesantren, gender, feminism

\section{Intisari}

Isu gender banyak diperbincangkan dalam karya sastra, baik karya sastra asing, sastra Indonesia, maupun sastra daerah. Isu gender tersebut juga muncul dalam sastra keagamaan dan atau sastra pesantren. Kebanyakan isu gender yang muncul dalam sastra keagamaan dan atau pesantren adalah isu bias gender atau ketimpangan gender yang dikukuhkan dengan dalil Alquran maupun hadits Rasulullah. Namun, dalam kajian sastra pesantren dengan pendekatan kritik sastra feminis terhadap Syi'ir Laki Rabi karya Haji Zakaria tidak menunjukkan bias gender. Hasil penelitian menunjukkan bahwa isu gender yang diangkat dalam puisi ini tidak sarat dengan bias gender. Sebab, karya ini sekalipun membicarakan kehidupan rumah tangga, tetapi isinya menekankan pada tugas, kewajiban, dan hak suamiistri.

Kata Kunci: syi'ir, sastra, pesantren, gender, feminisme

\section{Pendahuluan}

Isu gender dalam masyarakat muslim di dunia ini sering menjadi sorotan tajam para peneliti, baik peneliti mancanegara maupun peneliti sendiri. Islam sering dituduh sebagai agama yang negatif dalam menjalin hubungan antarmanusia, salah satu di antaranya adalah merepresi dan mengekang kaum perempuan dalam aktivitas sosial. Pendapat yang demikian itu bisa diketahui melalui hasil survei yang dikutip Jack G. Shaheen, guru besar emeritus Universitas Southern Illionis (Shaheen, 1997: 2-3) menyebutkan bahwa bahwa 62 
persen responden menyetujui terhadap pernyataan bahwa Muslim mengekang dan merepresi kaum perempuan. Angka demikian ini sangat tinggi, bahkan lebih tinggi dibanding dukungan Muslim terhadap terorisme, dan Muslim anti-Barat. Dari data itu pula tampak, bahwa Muslim itu dianggap membatasi atau "mengekang" perempuan dalam kehidupan sehari-hari termasuk berinteraksi ke ranah publik.

Senada dengan itu peneliti gender dari negeri ini pun sering menganggap bahwa Islam dengan kitab sucinya dan hadits Rasulnya, sering dinilai sebagai agama yang bias gender, yakni laki-laki adalah pemimpin bagi kaum perempuan; laki-laki diperbolehkan berpoligami hingga empat istri; suami ikut menentukan surga atau neraka bagi istrinya, dan banyak lagi yang lain. Kondisi demikian tidak terlepas dari para penafsir kitab suci dan hadits, yakni para kiai (ulama) yang pada umumnya laki-laki. Dari sudut pandang dunia laki-laki itulah, maka makin mengokohkan perempuan sebagai subordinat laki-laki meskipun banyak juga ayat-ayat kitab suci dan hadits Rasul yang mengusung kesetaraan atau meninggikan derajat kaum perempuan

Terkait dengan persoalan marjinalisasi perempuan oleh laki-laki menurut Wirjosutedjo dan Pradopo (2004: 309-321) tidak sepenuhnya disebabkan oleh laki-laki saja, tetapi juga disebabkan oleh kekuasaan dan keterbelakangan perempuan itu sendiri. Wujud marjinalisasi itu meliputi (a) perempuan sebagai kaum terjajah. (b) perempuan sebagai kaum buruh, (c) perempuan didominasi laki-laki, (d) perempuan tersubordinasi perempuan, (e) pemaksaan oleh perempuan, dan (f) perempuan didominasi oleh perempuan..

Persoalan isu gender yang demikian tidak hanya muncul pada fakta-fakta sosial dan kajian-kajian akademis terhadapnya semata. Namun, persoalan demikian pun dimunculkan dalam banyak karya sastra, baik karya sastra yang ditulis oleh pengarang laki-laki maupun perempuan, baik dalam sastra mancanegara maupun dalam negeri, baik dalam sastra Indonesia maupun sastra daerah, baik dalam sastra keagaamaan maupun dalam sastra umum. Meskipun banyak karya sastra Indonesia dan daerah mengisahkan tentang dunia perempuan, tetapi kebanyakan karya tersebut memosisikan perempuan sebagai subordinat laki. Bahkan karya yang ditulis pengarang pun juga demikian.

Perjuangan perempuan untuk memperoleh kesetaraan dengan laki-laki maupun perlawanan perempuan terhadap laki-laki dalam karya sastra Indonesia jumlahnya relatif sedikit. Di antara pengarang yang melahirkan karya demikian di antaranya adalah STA, 
NH. Dini, Pramoedya Ananta Toer, Ayu Utami, Abiedah el-Khalieqie, Dorothea Rosa Herliany, dan Jenar Mesa Ayu. Dua contoh penelitian terkait dengan perjuangan perempuan melawan hegemoni laki-laki dapat dilihat pada penelitian Mussaif terhadap novel Perempuan Berkalung Sorban karya Abiedah el-Khalieqie (2010) dan Gadis Pantai Karya Pramoedya Ananta Toer (2014).

Dalam khazanah sastra pesantren isu gender pun banyak diangkat dalam berbagai kitab kuning yang ditulis dalam bahasa Arab maupun kitab terjemahan, saduran, dan asli yang ditulis dalam bahasa Jawa. Beberapa hasil karya berbahasa Arab yang banyak dibicarakan terkait dengan bias gender adalah kitab Uqudul Lujjain karya Imam Nawawi Al-Bantani dan kitab Qurratul 'Uyuun karya Muhammad At-Tihami Ibnul Madani Kanun. Keduanya membicarakan persoalan hubungan suami-istri (hubungan seks) yang mengungkapkan dominasi kekuasaan suami terhadap istri. Kedua kitab tersebut banyak merujuk ayat Alquran dan hadits Rasul untuk mengukuhkan dominasi laki-laki terhadap perempuan. Terkait kajian kritik sastra feminis terhadap kitab Uqudul Lujjain dapat dilihat dalam tulisan Abdullah (2004).

Ada hal menarik dan fenomena yang langka yang akan dibicarakan di sini adalah hadirnya sastra pesantren yang berjudul Syi'ir Laki Rabi. Hal menarik yang perlu dicatat adalah jenis puisi tersebut mengangkat isu gender, tetapi tidak serta merta bias gender. Meskipun syi'ir ini membicarakan kehidupan berumah tangga antara laki-laki dan perempuan, tetapi cara pandang pengarangnya lebih mengarah pada isu kesetaraan gender. Sebab, syi'ir ini banyak membicarakan tugas, kewajiban, dan hak suami-istri. Jadi, sekalipun ada bias gender, tetapi kurang signifikan sebab syi'ir ini menguraikan tugas, kewajiban, dan hak suami-istri secara proporsional.

Syi'ir Laki Rabi yang menjadi objek penelitian ini, meskipun menjadi salah satu koleksi sastra pesantren yang dikoleksi Majlis Taklim Al-Mushlihun Kendal, tetapi menurut pengasuhnya karya tersebut adalah pemberian dari seorang mahasiswa Undip yang bernama Sagino pada tahun 1996. Syi'ir tersebut tidak tertulis tangan langsung oleh pengarangnya, tetapi terdokumentasi dalam bentuk cetak sederhana dengan menggunakan huruf Arab-Jawa (pegon) dan berbahasa Jawa Baru. Pada halaman sampul luar dan dalam buku ini hanya tertulis judul dan nama penerbit, tidak tertulis nama penulis atau pengarangnya. Namun, nama pengarangnya muncul dalam bait kelima syi'ir ini, yakni Haji Zakaria, yang berasal dari Kampung Pabean, Surabaya. Tahun pembuatan dan penerbitan 
buku ini juga tidak tertulis dengan jelas di buku. Namun, ada indikasi penerbitan buku itu pada tahun $1406 \mathrm{H}$ karena di halaman terakhir buku ini (hal.16) di bawah bait terakhir ada angka 1406 yang tertulis kecil dengan angka Arab.

\section{Metode Penelitian}

Objek material penelitian ini adalah naskah cetak Syi'ir Laki Rabi (selanjutnya disingkat $S L R)$ karya Haji Zakaria. Sedangkan objek formalnya adalah kesetaraan gender dalam sastra pesantren. Perspektif kajian pada penelitian ini bertolak pada ranah sosioliogi sastra, yaitu kajian feminisme. Karena pemerolehan data diambil dari objek materialnya, yakni buku, maka penelitian ini tergolong penelitian kepustakaan. Berkenaan dengan hal itu, maka metode pengumpulan data dalam penelitian ini adalah studi pustaka, yaitu mengumpulkan data terkait kesetaraan gender dalam sastra pesantren berdasarkan pada sumber-sumber tertulis yang berkaitan dengan objek penelitian.

Setelah terkumpul, data-data tersebut dianalisis dengan cermat dengan menggunakan /pendekatan soiologi sastra, khususnya perspektif feminisme atau kritik sastra feminis. Metode ini dipakai untuk menganalisis data pada aspek-aspek kesetaraan gender, terutama pada tugas, kewajiban, dan hak suami istri dalam membangun dan membina rumah tangga dalam kitab SLR. Hal ini sejalan dengan pendapat Swingwood dalam Damono (1984) yang menyatakan bahwa sastra bukan bahan sampingan saja dalam kehidupan, tetapi sastra adalah cerminan masyarakatnya meskipun ia menyadari bahwa sastra diciptakan pengarang dengan menggunakan seperangkat peralatan tertentu (Damono, 1984: 12; cf. Junus, 1986 dan Faruk, 1994)

\section{Hasil dan Pembahasan}

Sesuai judulnya SLR adalah jenis puisi yang berisi tentang laki-laki yang akan dan atau sudah menikah. Meskipun dari judulnya syi'ir ini membicarakan lelaki yang berumah tangga, tetapi isinya berisi nasihat bagi suami-istri yang membina rumah tangga. Meskipun sebenarnya sasaran utamanya adalah laki-laki (suami), tetapi pada keseluruhan bait-baitnya nasihat itu ditujukan pada pasangan suami istri. Untuk mengetahui gambaran isi $S L R$, perlu diperhatikan kutipan beberapa bait syi'ir berikut ini.

Ikilah syi'ir wong laki rabi

Kurang belanja aja pas kubi 
Becik kang sabar anut ing Nabi

Supaya rukun bisaha dadi

Akeh kedike becik anrima

Tibane rukun dadi utama

Lan aja tinggal waktu kang lima

Sebab sembahyang amal utama

Dadi wong lanang kang weruh dewe

Lamun wus rabi kang wani gawe

Jak sampek bojo kelawan utang

Tibane balak terus panggerang

Dadi wong wadon semono uga

Belanja gede abungah lega

Aja pas purik kang sarta duka

Supaya bojo atine suka

(SLR, hal. 2.

Dari kutipan tersebut tampak bahwa syi'ir ini ditujukan pada pasangan suami-istri dalam membina rumah tangga. Dalam kutipan tersebut dijelaskan bahwa dalam membina rumah tangga harus dilandasi dengan sabar sebagaimana ajaran Rasulullah. Bila dalam berumah tangga itu mendapat rizki yang sedikit atau banyak harus disyukuri dan menerima pemberian Tuhan itu dengan lapang dada. Yang demikian itu akan menjadikan rumah tangga tenang dan rukun. Di samping itu, untuk mendapatkan ketenangan dan kebahagiaan dalam berumah tangga, suami-istri itu harus menjalankan shalat lima waktu.

Hal penting lagi yang ditekankan dalam kutipan di atas adalah bahwasannya lelaki yang sudah membangun rumah tangga itu harus bertanggung jawab menafkahi istrinya dengan bekerja. Dengan bekerja suami dapat memberikan uang belanja pada sang istri sehingga ia dapat membeli barang-barang kebutuhan sehari-hari. Sebaliknya, jika suami tidak dapat memberi nafkah pada istrinya, maka bisa jadi istrinya akan hutang untuk membiayai kehidupan keluarganya. Bila istri banyak hutang, ia akan sedih dan menderita bahkan bisa jadi ia pulang pada keluarganya.

Bila kita telusuri bait per bait $S L R$ ini berisi nasehat atau amanat pengarang bagi suami maupun istri. Untuk menyistimatisasikan kajian terhadap SLR, maka pada 
pembahasan ini akan dideskripsikan tersendiri nasihat bagi lelaki (suami), nasihat bagi perempuan (istri), serta nasihat bagi pasangan suami-istri.

\section{Nasihat bagi Laki-Laki (Suami)}

Nasihat yang berupa amanat bagi laki-laki dalam SLR sangat banyak dan rinci. Sebab, macam-macam nasihat bagi laki-laki (suami) itu hampir muncul berbarengan dengan nasihat pada perempuan (istri) sepanjang bait-bait syi'ir ini. Untuk membedakan nasihat pada keduanya, maka dalam kajian ini kedua akan dibicarakan secara terpisah.

Lelaki itu harus bersifat dermawan pada istri, tidak boleh pelit pada sang istri sebab hal itu akan membuat sang istri menderita. Disarankan juga, lelaki harus tahu sendiri kewajibannya memberi nafkah pada istrinya, tidak menunggu istri meminta kebutuhan sehari-harinya (SLR, hal. 2).

Lelaki itu tidak diperkenankan minta istri untuk belanja barang atau makanan yang anehaneh dan sulit ditemukan barangnya (SLR, hal. 2).

Lelaki jangan senang keluar malam hari dan senang berpiknik terlebih berniat negatif untuk mencari kesenangan di luar. Sebab, jika hal itu diketahui sang istri maka akan menjadikan kehidupan rumah tangga yang tidak tentram di samping akan menghabiskan uang (SLR, hal. 3).

Lelaki itu harus mengerti perasaan seorang istri dan menahan atau menyimpan hal-hal kecil dari istrinya. Karena hal-hal kecil yang diungkapkan pada pasangannya bisa jadi malah menjadikan keharmonisan rumah tangga terkoyak (SLR, hal. 3).

\section{Nasihat bagi Perempuan (Istri)}

a. Perempuan (istri) harus mengerti kondisi suaminya. Saat suami sakit harus memperhatikan dan merawatnya. Uang belanja yang diberikan suami harus diatur secara hemat sehingga bisa menyisihkan uang belanja itu untuk keperluan yang lainnya. Bila istri bisa berhemat, maka suami akan menyayanginya. Sebab, dengan hidup hemat, maka rumah tangga itu dapat menabung untuk persiapan hari depan (SLR, hal. 2-3).

b. Perempuan harus thuma'ninah artinya ia harus tenang menghadapi berbagai persoalan rumah tangga dan betah tinggal di rumah. Perempuan juga dinasehatkan agar jangan 
suka bertandang ke rumah tetangga dengan tujuan untuk ngerumpi atau membicarakan kejelekan orang lain (SLR, hal 3).

c. Perempuan itu tidak diperkenankan berbicara ketus, terlebih pada suaminya. Sebab, jika ia suka berbicara ketus, maka hal itu akan menyakiti suaminya.

d.Perempuan itu harus bisa mengerjakan pekerjaan rumah tangga dengan cepat. Jika melayani suaminya pun tidak diperkenankan dengan lambat (SLR, hal. 3).

e. Perempuan harus tahu watak dasar suaminya, ia harus dapat menjaga perasaan suami. Bila perempuan mengerti watak suaminya maka kehidupan rumah tangganya menjadi tentram (SLR, hal. 3).

\section{Nasehat bagi Suami-Istri}

Selain berisi nasehat untuk para lelaki (suami) dan nasehat bagi perempuan (istri) secara seimbang dan proporsional, juga dijelaskan nasehat bagi keduanya dalam membangun keluarga sakinah. Sebelum kita kaji mendalam terkait hal itu, perhatikan kutipan bait-bait berikut ini.

Wong laki rabi becik kang bekti

Lanang lan wadon supaya berkati

Fardhu lan sunnah becik den angkat

Supaya rizki tekane rikat

Den pesti miskin becik sobarna

Syarahe kitab becik gatekna

Lanang wadon aja gawe lena

Supaya dosa dadi gak kena

Sugih lan miskin apa anane

Syukur wong kalih bagus karone

Lan ojo lali maring Pengerane

Supaya gampang mungguh rizkine

(SLR, hal. 5).

Bait-bait kutipan yang berisi nasehat di atas, bukan ditujukan pada salah satu dari pasangan suami-istri. Namun, nasehat itu ditujukan pada pasangan suami istri dalam membina keluarga sakinah. Bait pertama mengungkapkan agar pasangan suami istri itu saling berbuat baik dan setia serta selalu taat pada perintah Tuhan baik ibadah wajib 
maupun sunnah. Sebab dengan berbuat demikian, pasangan itu akan bertambah berkahnya dalam menjalani hidup di dunia. Jika diberi ujian kurang rizki atau miskin, suami-istri harus bersabar. Jangan terlena dengan kesedihan karena hal itu akan mendatangkan dosa. Oleh karena itu, pasangan suami-istri yang diuji itu mesti sabar, banyak berzikir, dan tetap bersyukur pada Tuhan. Dengan tetap bersyukur dalam suka maupun duka ini, maka Tuhan akan mempermudah mengucurkan rizki pada pasangan suami-itri tersebut.

Di samping berisi nasehat bagi pasangan untuk selalu berbuat baik, saling menyayangi, taat beribadah, dan selalu bersyukur dalam berbagai kondisi, SLR juga memberikan nasehat bagi pembaca khususnya bagi orang yang mau membina rumah tangga. Adapun nasehat itu di antaranya adalah cara memilih pasangan hidup, khususnya memilih seorang istri yaitu,

1. Memilih istri itu jangan berdasarkan pada kekayaannya, sebab hal itu menandakan kebodohan bagi pelakunya (SLR, hal. 5);

2. Memilih istri itu harus berdasarkan pada kebaikan budi pekertinya sekalipun yang bersangkutan itu adalah golongan miskin (SLR, hal. 5-6);

3. Istri yang baik adalah yang berwatak hemat. Sebab, meskipun suami penghasilannya sedikit apabila beristri hemat, maka lambat laun akan menjadi kaya karena sedikit demi sedikit ia akan menyisihkan sisa uang belanja (SLR, hal. 6-7);

4. Istri yang baik adalah yang pandai bersyukur, menerima kelebihan dan kekurangan sang suami (SLR, hal. 7).

Di samping SLR memberi rambu-rambu bagi seorang laki-laki yang akan menikahi seorang perempuan, pengarang juga mengingatkan pada seorang laki-laki yang telah menikah agar tidak melakukan hal-hal berikut ini.

1. Lelaki (suami) harus setia pada istrinya, jangan mudah tergoda untuk menambah istri lagi meskipun istri yang telah dinikahinya itu sudah tampak tua (SLR, hal. 7);

2. Lelaki (suami) tidak diperkenankan memenuhi semua permintaan istri dengan tujuan menyenangkan hatinya semata-mata terlebih sampai berhutang banyak pada kerabat dan tetangganya (SLR, hal. 7);

3. Lelaki (suami) juga harus bisa berhemat dalam mengelola harta benda yang dihasilkan dan dimilikinya serta dapat menyisihkan hartanya untuk ditabung sekalipun hidupnya berkecukupan (SLR, hal. 8); 
4. Lelaki (suami) jangan sering keluar malam sebab hal itu bisa jadi akan menimbulkan fitnah yang berdampak pada hancurnya rumah tangga ( $S L R$, hal. 8).

Dari data di atas, sangat jelas bahwa kedudukan suami-istri dalam SLR diposisikan setara, tidak tampak adanya ketimpangan gender atau bias gender. Meskipun penulisnya seorang laki-laki, tetapi sepanjang syi'ir yang ditulisnya tidak ada hegemoni laki-laki (suami) atas perempuan (istri). Nasehat yang ditawarkan lebih mengarah pada hak, kewajiban, tugas tanggung jawabnya masing-masing, baik sebagai suami maupun istri. Jadi, posisi suami dan istri dalam membina keluarga itu bukan sebagai atasan dan bawahan, yang memerintah dan yang diperintah, tetapi lebih sebagai team work yang saling membutuhkan dengan tugas dan tanggung jawab yang berbeda.

\section{Simpulan}

Dari kajian gender terhadap $S L R$, tampak bahwa dunia pesantren yang dijustifikasi para peneliti sebagai dunia (komunitas) yang bias gender yang dianggap memarjinalkan perempuan tidak terbukti di sini. Sebab, dalam SLR tidak sedikit pun persoalan itu diangkat oleh pengarangnya meskipun syi'ir itu mengungkap hubungan laki-laki dan perempuan. Padahal kalau dibandingkan teks-teks pesantren yang lain, seperti kitab Uqudullujain dan Qurratul 'Uyun yang sangat jelas mengungkapkan bahwa laki-laki (suami) itu sangat berkuasa atas perempuan (istri). Hal itu menjadi sangat aneh dalam komunitas pesantren. Jadi, hadirnya $S L R$ sebagai sastra pesantren yang tidak mengangkat hegemoni lelaki atas perempuan itu dapat dikategorikan sebagai bentuk pemberontakan terhadap dunia pesantren.

\section{Daftar Pustaka}

Abdullah, Muhammad. 2004. Dekonstruksi Sastra Pesantren. Semarang: Fasindo.

Damono, Sapardi Djoko. 1984. Sosiologi Sastra: Sebuah Pengantar Ringkas. Jakarta: Pusat Pembinaan dan Pengembangan Bahasa.

Faruk. 1994. Pengantar Sosiologi Sastra. Yogyakarta: Pustaka Pelajar.

Junus, Umar. 1986. Sosiologi Sastra: Persoalan Teori dan Metode. Kuala Lumpur: Dewan Bahasa dan Pustaka. 
Mussaif, Moh. Muzakka. 2010. "Perjuangan Perempuan Melawan Hegemoni Patriarki: Kajian terhadap Novel Perempuan Berkalung Sorban karya Abidah El-Khalieqie" dalam Kajian Sastra.

2014. "Pandangan Pramoedya Ananta Toer terhadap Priyayi-Santri: Kajian Terhadap Novel Gadis Pantai" Dipresentasikan dalam Seminar Internasional dalam rangka PIBSI di Universitas Ahmad Dahlan Yogyakarta.

Shaheen, Jack G. 1997. Arab and Muslim Stereotyping in American Populer Culture. Washington D.C.: Center for Muslim-Christian Understanding, History and International Affairs, Edmund A. Walsh School of Foreign Service, Georgetown University.

Wirjosutedjo, MN dan Rahmat Djoko P. 2004. "Marjinalisasi Perempuan dalam Bekisar Merah dan Belantik Karya Ahmad Thohari: Tinjauan Kritik Sastra Feminis". Humanika, Vol.17/No.3 (Juli).

Zakaria, Haji. 1984 (?). Syi'ir Laki Rabi. Surabaya: Maktabah Saikh Salim bin Said Nabhan. 